\title{
Growth and Soil Nutrient Responses to Stocking Rate and Nitrogen Source for Mid-Rotation Loblolly Pine in West-Central Arkansas
}

\author{
David M. Burner ${ }^{*}, 1$, Daniel H. Pote ${ }^{1}$, Charles T. MacKown ${ }^{2}$ and E. David Dickens ${ }^{3}$ \\ ${ }^{I}$ USDA ARS DBSFRC, 6883 South State Highway 23, Booneville, AR, 72927, USA \\ ${ }^{2}$ USDA ARS GRL, 7202 W. Cheyenne St., El Reno, OK, 73036, USA \\ ${ }^{3}$ Daniel B. Warnell School of Forestry and Natural Resources, University of Georgia, Athens, GA, 30602, USA
}

\begin{abstract}
Fertilization is needed to replace nutrients removed from pine straw plantations, but tree response to fertilization could be influenced by stocking rate. Our objective was to determine effects of three $\mathrm{N}$ fertilizer sources on loblolly pine (Pinus taeda L.) growth and pine straw yield as a function of stocking rate (trees ha ${ }^{-1}$, TPH) at about midrotation (12-14 years post-planting). Commercial mineral fertilizer (CF), poultry litter (PL, $5.4 \mathrm{Mg} \mathrm{ha}^{-1}$ ), and pelletized poultry litter (PPL, 4.6 $\mathrm{Mg} \mathrm{ha}^{-1}$ ) were applied once in April 2006 at 0 (control) and $200 \mathrm{~kg} \mathrm{ha}^{-1}$ of N at plantation stocking rates of 2300, 1200, and 970 TPH near Booneville, AR. Basal area (range 32.6 to $42.8 \mathrm{~m}^{2} \mathrm{ha}^{-1}$ ) was very high and did not respond to fertilization, and pine straw yield also did not consistently increase with fertilization compared to the control. Concentrations of pine straw $\mathrm{N}$ and foliar $\mathrm{N}$ increased with fertilization, especially with $\mathrm{CF}$ compared to litter. Topsoil $\mathrm{NO}_{3}{ }^{-}-\mathrm{N}$ and $\mathrm{NH}_{4}{ }^{+}-\mathrm{N}$ were greater for $\mathrm{CF}$ than PL and PPL 3 mo after fertilization, but responses $\geq 9$ mo after application did not differ from the control. While the plantations were able to acquire $\mathrm{N}$, overstocking seemed to constrain $\mathrm{N}$ utilization for increased BA or foliage production. Thinning should improve tree growth and pine straw yield responses to fertilizer applied at mid-rotation.
\end{abstract}

Keywords: Basal area, pine straw, Pinus taeda L., poultry litter, soil N.

\section{INTRODUCTION}

Demand for timber products in the US is projected to nearly double from 1994 to 2050, with the southeastern region expected to be the major source of expansion in softwood timber supply [1]. About 9 million ha in the southern US, much of it marginal crop and pastureland, could be converted to pine plantations to alleviate anticipated increases in prices of timber products [2]. Loblolly pine (Pinus taeda L.), one of the southern yellow pines, is the leading timber species in the US, predominating on 13.4 million ha and representing about 1.4 billion $\mathrm{m}^{3}$ of southern pine growing stock [3]. The Ouachita region of Arkansas has 71 million $\mathrm{m}^{3}$ of southern pine growing stock on 520 thousand ha [4]. Besides timber, this resource also offers tremendous untapped economic potential for pine straw production.

Pine straw is a renewable non-timber forest product widely used as a landscape mulch for highway, commercial, and residential applications [5]. Landowners with plantations of southern pines can realize a cash flow from selling pine straw early in the tree rotation, perhaps as early as 8 years after planting (depending on spacing), and this early return can be an important component to whole-farm economic viability [D.M. Burner et al., 2009, unpublished data; 6-8]. Yield of loblolly pine straw in the southeast US commonly ranges from 4.2 to 7.7 Mg ha ${ }^{-1}[9,10]$, valued at about $\$ 250 \mathrm{ha}^{-1}$ or $\$ 62$ million in 2006, a $161 \%$ increase from 2005 [11].

Address correspondence to this author at the USDA-ARS, 6883 South State Hwy. 23, Booneville, AR 72927, USA; Tel: 479-675-3834, Ext. 326; Fax: 479-675-2940; E-mail: David.Burner@ARS.USDA.GOV
As for any conventional agricultural or silvicultural practice, fertilization of pine straw plantations is important either early in the rotation, and is generally considered a best management practice at about mid-rotation after the first thinning $[10,12]$. Plantations also may be fertilized at least 3 to 4 years before thinning or harvesting for the residual tree stand to realize the most benefit to enhancing pine straw production and wood volume [10]. Southern pines usually respond to fertilization when foliar $\mathrm{N}$ and $\mathrm{P}$ concentrations are $\leq 12.0$ and $1.2 \mathrm{~g} \mathrm{~kg}^{-1}$ [13], respectively. Poultry litter (PL) has been suggested for forest fertilization as an effective, environmentally sound, and less expensive $\mathrm{N}$ source than commercial fertilizer (CF) $[14,15]$. While landowners have a choice of fertilizers, however, they may not be convinced of the inherent cost-benefit economics of fertilization per se [14].

When plantation-grown loblolly pine was measured 4 years after a single surface application of either $15.7 \mathrm{Mg} \mathrm{ha}^{-1}$ PL or CF (diammonium phosphate plus urea), stem diameter at $1.3-\mathrm{m}$ above soil surface (dbh) tended $(P<0.10)$ to be greater with $\mathrm{PL}$ than $\mathrm{CF}$, but not stem volume $(P>0.23)$ [16]. The single application was equivalent to $112 \mathrm{~kg} \mathrm{ha}^{-1}$ of total $\mathrm{N}$, comparable to that recommended for an emulated loblolly pine silvopasture [17].

Pine spacing and management often are objective-driven (including goals of tree farming activities) and site specific (varying with pine species, soil characteristics, harvest frequency, rotation length, and fertilization regime), but there has been little production [8] or pine straw research for Arkansas [18, 19]. The knowledge database needs to be expanded to enable growers to match plantation stocking rate 
and fertility management with specific growing conditions, goals, and budget.

Our objective was to determine effects of three $\mathrm{N}$ fertilizer sources on loblolly pine (Pinus taeda L.) growth and pine straw yield as a function of stocking rate (trees ha ${ }^{-1}$, $\mathrm{TPH}$ ) at about mid-rotation (12-14 years post-planting). We hypothesized that fertilization would significantly increase tree growth and pine straw yield compared to the control.

\section{MATERIALS AND METHODS}

The experimental site was located near Booneville, AR at $150 \mathrm{~m}$ above sea level $\left(35^{\circ} \mathrm{N}, 94^{\circ} \mathrm{W}\right)$. Soil was predominantly Leadvale silt loam (fine-silty, siliceous, semiactive, thermic Typic Fragiudult) on a 1 to $3 \%$ slope. Depth to friable shale is $\geq 1.2 \mathrm{~m}$ [20], but a restrictive fragipan occurs at 40 to $60 \mathrm{~cm}$ depth [17]. The site index for loblolly pine is about $20 \mathrm{~m}$ at 25 years [21].

In spring 1994, one-year-old loblolly pine seedlings selected for increased growth rate [22] were planted in eastwest row orientation in one of three 0.4 ha spatial designs (plots): 1.2 (within row) x $2.4 \mathrm{~m}$ (between row), $2.4 \times 2.4 \mathrm{~m}$, and $3.6 \times 2.4 \mathrm{~m}$ in a randomized complete block design with three replications. The $1.2 \times 2.4,2.4 \times 2.4$, and $3.6 \times 2.4 \mathrm{~m}$ plots were a subset of those previously described [23], and had the equivalent of 2300, 1200, and $970 \mathrm{TPH}$, respectively, in April 2006. All plots had closed canopies when the study was initiated. The site was used as meadow for decades, and received no lime or fertilizer input for an undetermined number of years before tree planting or prior to imposing experimental treatments. Tree branches were pruned from soil surface to about $2 \mathrm{~m}$ stem height in winter 2004, and pruning debris removed from the site. Trees were not pruned during the remainder of the test.

Fertilization treatments consisting of control (no fertilization), untreated PL, pelletized poultry litter (PPL), and $\mathrm{CF}\left(\mathrm{NH}_{4} \mathrm{NO}_{3}\right.$, ) were assigned at random to subplots $(9.7 \mathrm{~m}$ wide [five tree rows] x $30 \mathrm{~m}$ long) in a randomized complete block design with three replications, and broadcast (surface) applied in early April 2006 prior to first thinning [10]. Treatments were designed to supply equivalent $\mathrm{N}$ loading rates of $200 \mathrm{~kg} \mathrm{ha}^{-1}$ of elemental $\mathrm{N}$ for each fertilizer treatment. Litter rates were equivalent to 5.4 and $4.6 \mathrm{Mg} \mathrm{ha}^{-1}$ for PL and PPL, respectively. Triple super phosphate and $\mathrm{KCl}$ applied individually in $\mathrm{CF}$ supplied $\mathrm{P}\left(100 \mathrm{~kg} \mathrm{ha}^{-1}\right)$ and $\mathrm{K}\left(150 \mathrm{~kg} \mathrm{ha}^{-1}\right)$ at approximately the same rate as that applied in the PL and PPL fertilizers. Adjustments among the fertilizer sources for other macro- and micro-nutrients were not made.
The PPL was commercially available as Microstart60 (Perdue AgriRecycle, Seaford, DE), an organic, pasteurized, pelletized form of poultry litter (poultry species unknown) with a presumptive elemental N-P-K nutrient composition of 40,20 , and $30 \mathrm{~g} \mathrm{~kg}^{-1}$, respectively) [24]. Untreated, dry PL [rice (Oryza sativa L.) hull bedding] was obtained from a commercial broiler (Gallus gallus domesticus L.) operation. The two litter fertilizers were analyzed for chemical and nutrient concentrations (dry basis) by the University of Arkansas diagnostic laboratory (Fayetteville, AR), which confirmed the presumptive elemental N-P-K concentrations of PPL, and that PL and PPL had similar chemical and nutrient composition (Table $\mathbf{1}$ ).

A composite sample of first-flush foliage was collected from the upper one-third of five tree crowns plot $^{-1}$ in July 2005 (pre-test), oven dried at $60{ }^{\circ} \mathrm{C}$, and analyzed for $\mathrm{N}$ by combustion (Vario Max CN, Elementar Americas, Inc., Mt. Laurel, NJ) to examine baseline concentration. While this preliminary sample was not dormant season foliage as recommended [25], mean $\mathrm{N}$ concentration was $12.4 \mathrm{~g} \mathrm{~N} \mathrm{~kg}^{-1}$ (range 10.6 to $15.0 \mathrm{~g} \mathrm{~N} \mathrm{~kg}^{-1}$ ). Foliage was subsequently sampled in July 2006 and 2007, and January 2007 and 2008 $[25,26]$ and analyzed for $\mathrm{N}$ as described above.

One of the center three rows in each subplot was randomly selected, permanently marked, and co-dominant tree dbh was measured by diameter tape on 21 March 2006 (pre-test), 28 November 2006, and 31 March 2009. Basal area (BA) was calculated from mean dbh [27] for subplots and replications:

BA $\left(\mathrm{m}^{2} \mathrm{ha}^{-1}\right)=\mathrm{TPH}\left(\pi \mathrm{dbh}^{2} / 40,000\right)$

where dbh was measured outside bark, $\mathrm{cm}$.

A permanent sub-subplot ( $5 \mathrm{~m}$ long $\times 2.4 \mathrm{~m}$ wide) was situated in an alley near the center of each subplot, and all accumulated pine straw and duff layer was removed in spring 2006 (pre-test). Yield of dry $\left(60{ }^{\circ} \mathrm{C}\right)$ pine straw was measured annually in November 2006, October 2007, and November 2008 in a $1 \mathrm{~m}^{2}$ quadrat located at random within the permanent sub-subplot. A sample of pine straw was ground in a Wiley mill (Arthur Thomas Co., Philadelphia, PA) to pass a $1 \mathrm{~mm}$ screen and stored at $-20{ }^{\circ} \mathrm{C}$ prior to $\mathrm{N}$ analysis by combustion (Vario Macro CN, Elementar Americas, Inc., Mt. Laurel, NJ). Yield of pine straw was expressed as $\mathrm{Mg}$ dry mass $\mathrm{ha}^{-1} \mathrm{yr}^{-1}$. Following harvests, residual pine straw and duff layer was removed from the sub-subplot and discarded. The few weeds present within sub-subplots were controlled using spot applications of herbicides.

Table 1. Chemical and Nutrient Analysis of Poultry Litter (PL), Microstart60 Pelletized Poultry Litter (PPL), and Commercial Fertilizer (CF) Applied to Loblolly Pine Stands Near Booneville, AR

\begin{tabular}{|c|c|c|c|c|c|c|c|}
\hline Fertilizer & $\mathbf{p H}^{\mathrm{a}}$ & $\mathbf{E C}^{\mathbf{b}}$ & $\mathbf{N}$ & $\mathbf{P}$ & K & $\mathrm{Ca}$ & C \\
\hline PL & 7.5 & 10700 & 37.4 & 15.0 & 26.6 & 22.3 & 344.6 \\
\hline $\mathrm{CF}^{\mathrm{c}}$ & $\mathrm{ND}^{\mathrm{d}}$ & ND & 340.0 & 200.7 & 498.1 & ND & ND \\
\hline
\end{tabular}

${ }^{\mathrm{a}} 1: 2$ litter:water, volume basis.

${ }^{\mathrm{b}}$ Electrical conductivity.

${ }^{\mathrm{c}}$ Based on labeled composition.

${ }^{\mathrm{d}}$ Not determined. 
Topsoil (0 to $10 \mathrm{~cm}$ depth), excluding surface duff layer, was sampled from each subplot in April 2006 (0 mo following fertilization), July 2006 (3 mo), January 2007 (9 mo), July 2007 (15 mo), and January 2008 (21 mo). Soil samples were air-dried, ground in a mortar to pass a $1.4 \mathrm{~mm}$ screen, and analyzed for $\mathrm{N}$ and $\mathrm{C}$ by combustion (Leco FP428, Leco Corp., St. Joseph, MI), and the ratio of $\mathrm{C} / \mathrm{N}$ was calculated. Topsoil was analyzed for mineral $\mathrm{N}$ by extracting with $1.0 \mathrm{M} \mathrm{KCl}$. Extracted $\mathrm{NH}_{4}-\mathrm{N}$ was assayed by colorimetry and $\mathrm{NO}_{3}-\mathrm{N}$ by Cd-reduction coupled colorimetry using procedures for an automated discrete analyzer (AQ2, SEAL Analytical US Inc., Mequon, WI). Topsoil was analyzed for $\mathrm{pH}(1: 1$, topsoil:water, $\mathrm{w}: \mathrm{v}, 5$ min mixing followed by $1 \mathrm{~h}$ equilibration), $1.0 \mathrm{M} \mathrm{KCl}$ extractable $\mathrm{Al}$ [28], and Mehlich III extractable P [29].

To characterize climatic conditions, air temperature and rainfall, measured $1.4 \mathrm{~m}$ above soil surface, were continuously recorded at $0.5 \mathrm{~h}$ intervals from 1 April 2006 through 31 January 2008 at an unshaded weather station located $1.3 \mathrm{~km}$ northwest of the pine plantation. Air temperature was measured with a Model 3667 external temperature probe (Spectrum Technologies, Inc, Plainfield, IL), and rainfall was measured with a Model 3525R tipping bucket rain gauge (Spectrum Technologies, Inc, Plainfield, IL). Data were averaged (air temperature) or summed (rainfall) across months. Long-term (1971 to 2000) mean monthly air temperature and rainfall were from an official weather station located $7.0 \mathrm{~km}$ east of the pine plantation [30].

Analysis of variance (ANOVA) used a mixed linear model, Proc Mixed [31]. Fixed effects were sampling date, stocking rate, fertilization treatment, and their interactions. Sampling date was month $(0,3,9,15$, and 21 mo after fertilization) or year depending on variable. Data were analyzed by repeated measures [32] with a first-order autoregressive covariance structure using sampling date as the repeated effect. Replication and its interactions with fixed effects were random effects. The model used a restricted maximum likelihood estimation method with degrees of freedom calculated by the Satterthwaite approximation method. Means were considered different at $P<0.05$ using Tukey's honest significant difference (HSD) test. Trends and interactions were further examined using the Reg procedure [31].

\section{RESULTS}

Mean monthly air temperatures were usually greater than the long-term mean during the study interval, but followed the same general trend (Fig. 1). The rainfall pattern during the study interval diverged substantially from the long-term mean, but mean rainfall for the interval $\left(90.2 \mathrm{~mm} \mathrm{mo}^{-1}\right)$ was similar to the long-term mean $\left(102.1 \mathrm{~mm} \mathrm{mo}^{-1}\right)$.

\section{Tree Growth}

Tree dbh was significantly affected by year, stocking rate, and the year $\mathrm{x}$ stocking rate interaction, but was not significantly affected by fertilizer treatment and its interactions $(P \geq 0.18)$. The year $\mathrm{x}$ stocking rate interaction appeared to be caused by a different rate of change (slope) in dbh with month at the three stocking rates (Fig. 2). Across years, tree dbh differed with stocking rate on the order $970>$ $1200>2300(21.2,19.0$, and $15.0 \mathrm{~cm}$, respectively).
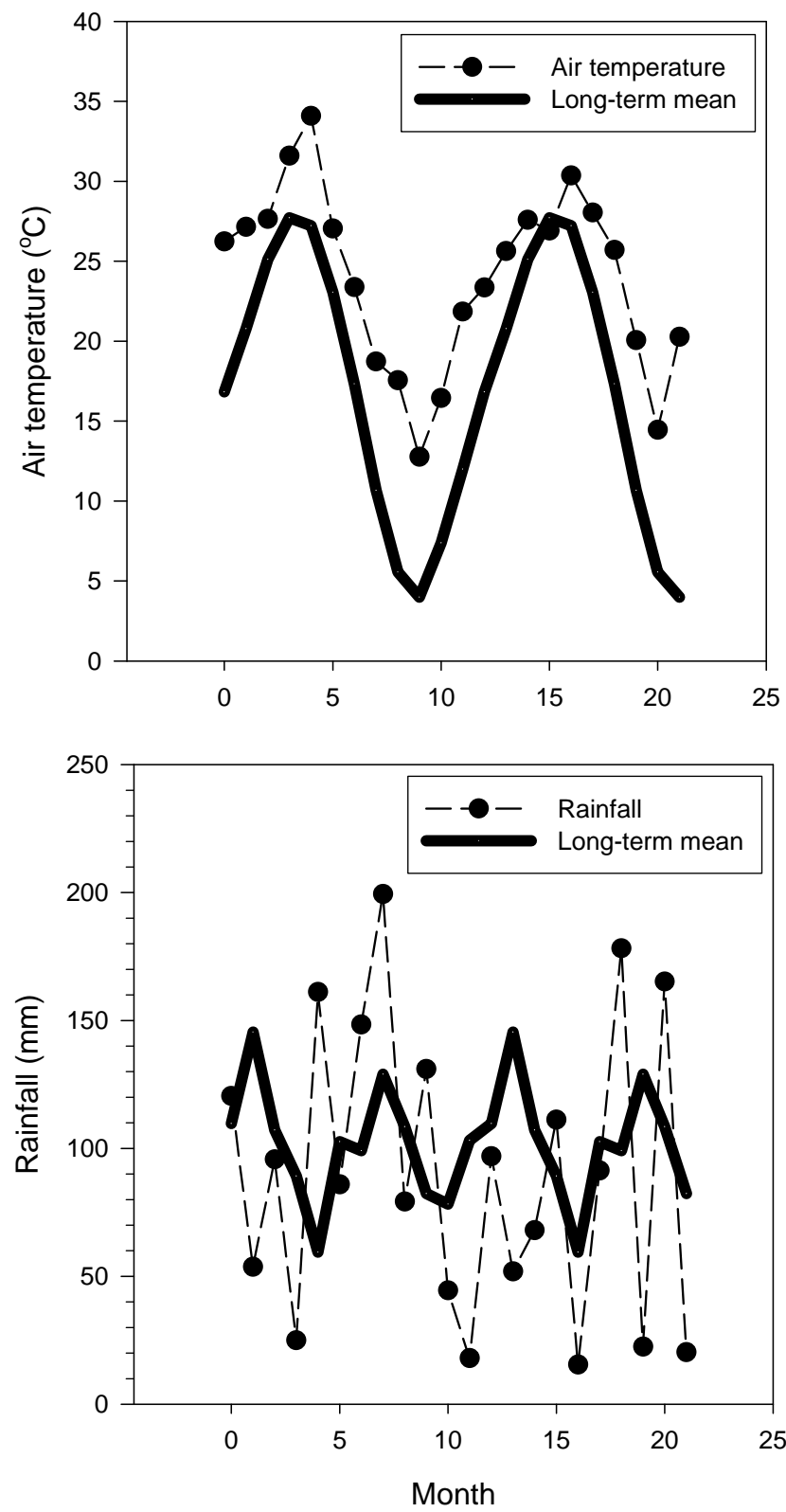

Fig. (1). Monthly climatic conditions near Booneville, AR from April 2006 (month 0) through January 2008 (month 21). Long-term mean air temperature and total rainfall were for the period 1971 to 2000 from a station located $7.0 \mathrm{~km}$ east of the experimental site [28].

Estimated BA was significantly $(P \leq 0.01)$ affected by year, stocking rate, and stocking rate $\mathrm{x}$ fertilizer interaction, but not for the year $\mathrm{x}$ stocking rate interaction $(P=0.23)$. The stocking rate $\mathrm{x}$ fertilizer interaction appeared to be caused by differing responses of BA to TPH (Fig. 3); and only PL caused a significant BA response to TPH $(P=0.01)$. For any given fertilizer, BA at the $2300 \mathrm{TPH}$ stocking rate (range 39.7 to $42.8 \mathrm{~m}^{2} \mathrm{ha}^{-1}$ ) usually exceeded that of the other stocking rates, range 32.6 to $35.5 \mathrm{~m}^{2} \mathrm{ha}^{-1}$.

\section{Foliar Responses}

Pine straw yield was significantly affected by year, stocking rate, fertilizer, and the year $\mathrm{x}$ fertilizer interaction. Pine straw yield tended $(P \geq 0.04)$ to decrease with time with or without fertilization (Fig. 4), but regression responses 


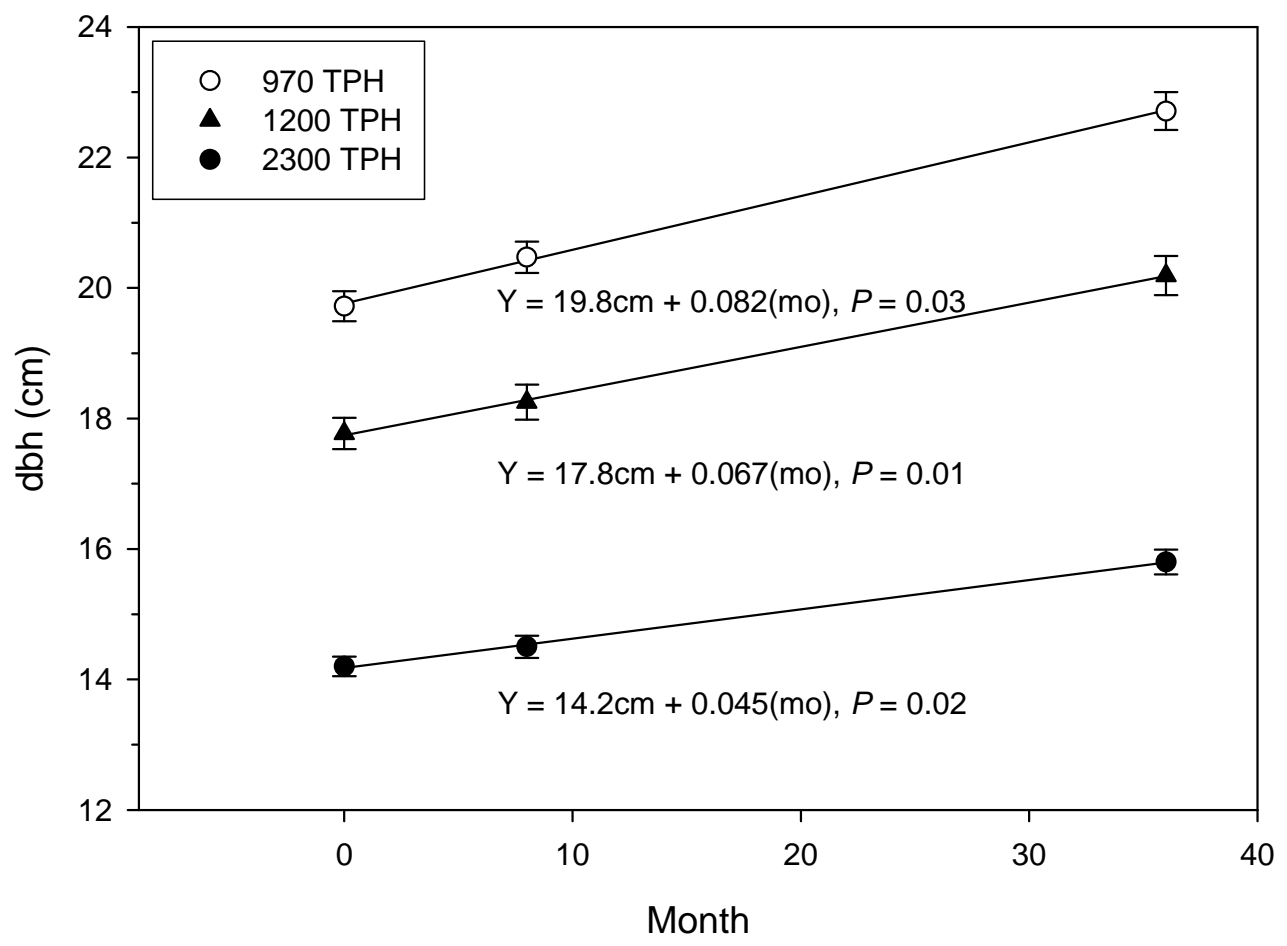

Fig. (2). Temporal change in dbh at three stocking rates (number trees $\mathrm{ha}^{-1}$, TPH) for loblolly pine plantations near Booneville, AR.

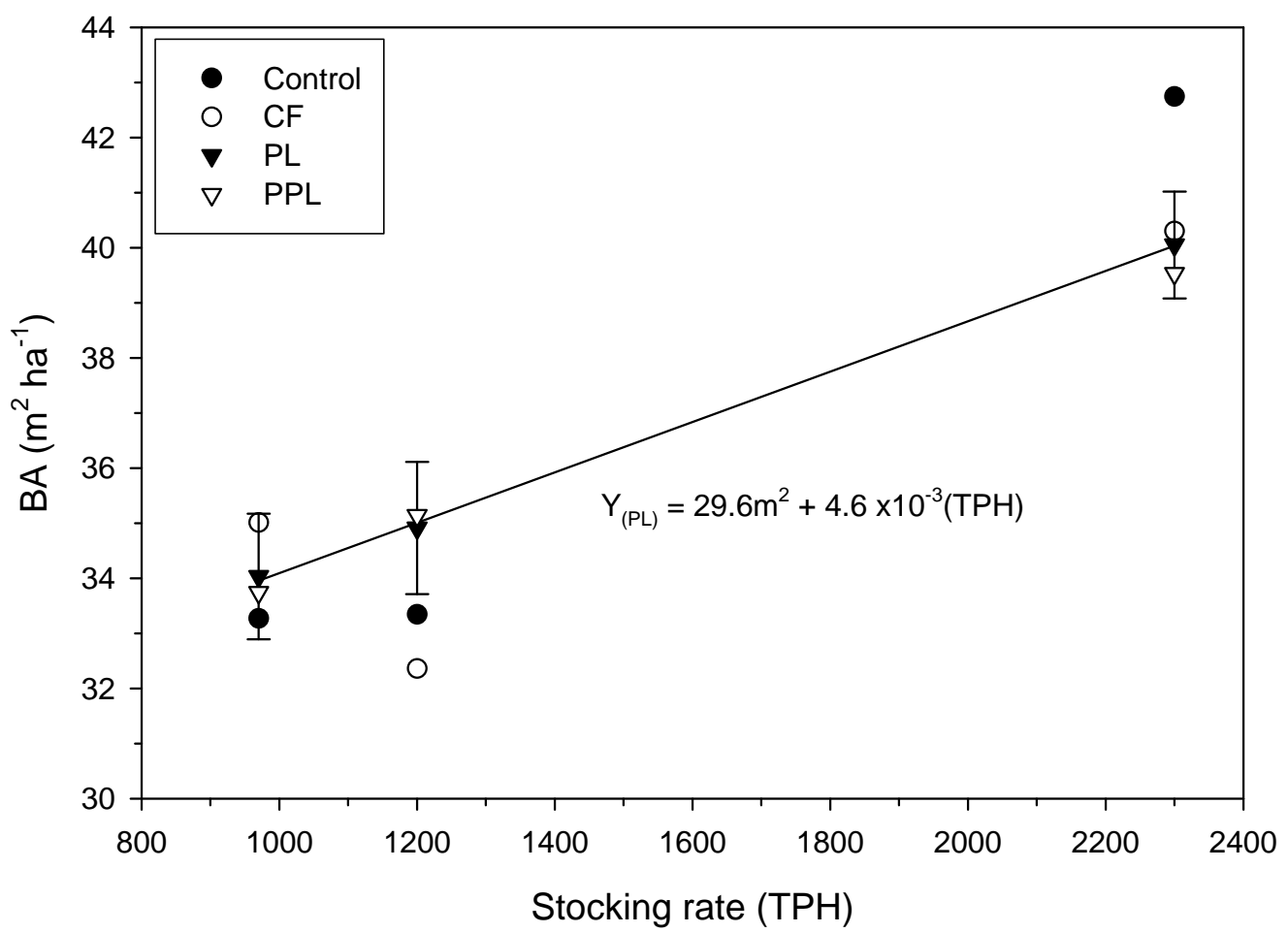

Fig. (3). Change in basal area (BA) with stocking rate (trees ha $\left.{ }^{-1}, T P H\right)$ and fertilization (Control, CF $=$ commercial fertilizer, PL $=$ poultry litter, and PPL = pelletized poultry litter) for loblolly pine plantations near Booneville, AR. Only PL had a significant regression response $(P=0.01)$. For clarity, SE bars are shown only for PL means.

were significant only for $\mathrm{CF}(P=0.04)$. Mean pine straw yield was greater for PL than PPL in 2006, PL yielded more $(P=0.06)$ than the control in 2007 , and treatments means did not differ in 2008. Across years, the control (4.6 $\left.\mathrm{Mg} \mathrm{ha}^{-1} \mathrm{yr}^{-1}\right)$ yielded 9.4 and $12.4 \%$ less $(P \leq 0.03)$ pine straw than plots receiving CF (5.0 Mg ha $\mathrm{yr}^{-1}$ ) or PL (5.2 $\mathrm{Mg} \mathrm{ha}^{-1} \mathrm{yr}^{-1}$ ), respectively, but yield did not differ for the control and PPL (4.9 $\left.\mathrm{Mg} \mathrm{ha}^{-1} \mathrm{yr}^{-1}\right)(P=0.33)$. Yield of pine straw was greater at $1200\left(5.2 \mathrm{Mg} \mathrm{ha}^{-1} \mathrm{yr}^{-1}\right)$ than $970 \mathrm{TPH}\left(4.7 \mathrm{Mg} \mathrm{ha}^{-1} \mathrm{yr}^{-1}\right)$, while yield at $2300 \mathrm{TPH}$ was intermediate $\left(4.8 \mathrm{Mg} \mathrm{ha}^{-1} \mathrm{yr}^{-1}\right)$. 


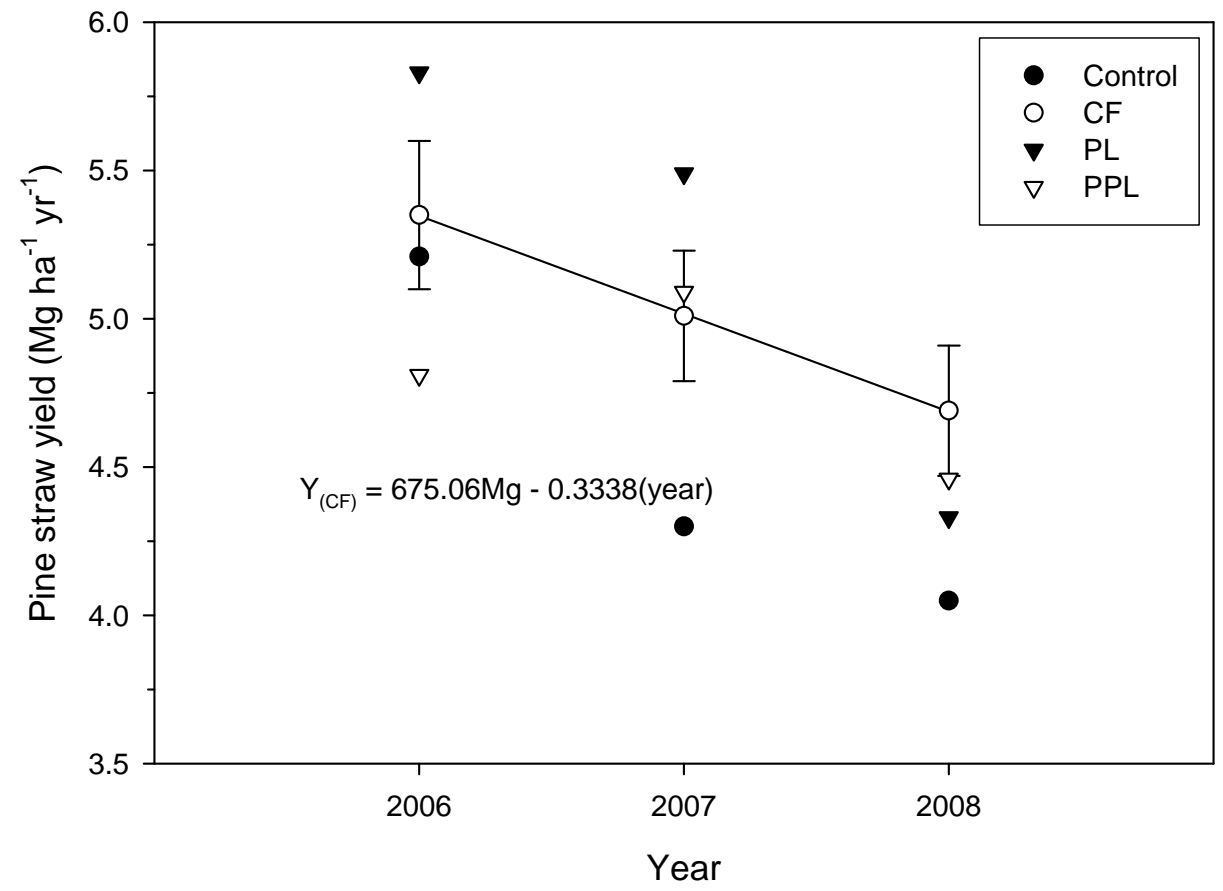

Fig. (4). Change in loblolly pine straw yield with stocking rate (number trees ha $^{-1}$, TPH) and fertilization $(\mathrm{Control}$, $\mathrm{CF}=\mathrm{commercial}$ fertilizer, $\mathrm{PL}=$ poultry litter, and PPL = pelletized poultry litter) for plantations near Booneville, AR. Only the regression response for CF was significant $(P=0.04)$. For clarity, SE bars are shown only for $\mathrm{CF}$ means. Fertilizer means within a year followed by a common letter do not differ $(P>0.05)$.

Pine straw $\mathrm{N}$ concentration was significantly affected by year, stocking rate, and fertilization. Pine straw $\mathrm{N}$ concentration increased across years in the order $2006(6.4 \mathrm{~g}$ $\left.\mathrm{kg}^{-1}\right)<2007\left(6.9 \mathrm{~g} \mathrm{~kg}^{-1}\right)<2008\left(10.0 \mathrm{~g} \mathrm{~kg}^{-1}\right)$, an indirect indication of fertilization response. The 2300 and $1200 \mathrm{TPH}$ stocking rates (both $7.9 \mathrm{~g} \mathrm{~N} \mathrm{~kg}^{-1}$ ) had greater pine straw $\mathrm{N}$ than the $970 \mathrm{TPH}$ stocking rate $\left(7.5 \mathrm{~g} \mathrm{~kg}^{-1}\right)$. Fertilization increased pine straw $\mathrm{N}$ concentration (7.8 to $8.1 \mathrm{~g} \mathrm{~kg}^{-1}$ ) compared to the control $\left(7.1 \mathrm{~g} \mathrm{~N} \mathrm{~kg}^{-1}\right)$. Averaged across fertilizer treatments, $\mathrm{N}$ removals in harvested pine straw were greater at $1200 \mathrm{TPH}\left(41 \mathrm{~kg} \mathrm{ha}^{-1} \mathrm{yr}^{-1}\right.$ of N) than $(970$ TPH (34 kg ha $\mathrm{yr}^{-1}$ of $\mathrm{N}$ ), with $2300 \mathrm{TPH}$ being intermediate (38 kg ha-1 $\mathrm{yr}^{-1}$ of N). Ignoring potential losses through leaching, runoff, and denitrification, additions from mineralization, and utilization for tree growth, this would be equivalent to about 5 years production from a single application of $200 \mathrm{~kg} \mathrm{ha}^{-1}$ of $\mathrm{N}$ fertilizer.

Foliar $\mathrm{N}$ was significantly affected by sampling date and fertilizer. There was a progressive increase $(P=0.01)$ in foliar $\mathrm{N}$ from July $2005\left(12.3 \mathrm{~g} \mathrm{~kg}^{-1}\right)$ to July $2007\left(18.1 \mathrm{~g} \mathrm{~kg}^{-1}\right)$, followed by a decrease to $15.8 \mathrm{~g} \mathrm{~kg}^{-1}$ in January 2008 . This suggested that a foliar response to fertilization diminished within 2 years after application. Across sampling dates, fertilization increased $(P=0.01)$ foliar $\mathrm{N}$ (range 15.5 to $15.8 \mathrm{~g}$ $\left.\mathrm{kg}^{-1}\right)$ compared to the control $\left(14.3 \mathrm{~g} \mathrm{~kg}^{-1}\right)$.

\section{Topsoil Nutrients}

There was a significant sampling date $\mathrm{x}$ fertilizer interaction for topsoil $\mathrm{NO}_{3}{ }^{-} \mathrm{-N}$ and $\mathrm{NH}_{4}{ }^{+}-\mathrm{N}$, caused by spikes in these $\mathrm{N}$ fractions 3 mo after fertilizer application. At 3 mo, topsoil $\mathrm{NO}_{3}{ }^{-}-\mathrm{N}$ was greater for $\mathrm{CF}$ than PL and PPL, and the litter amendments had more $\mathrm{NO}_{3}{ }^{-} \mathrm{N}$ than the control (Fig. 5). Topsoil concentrations of $\mathrm{NO}_{3}{ }^{-} \mathrm{N}$ at 9 and $15 \mathrm{mo}$ were slightly elevated compared to that at $0 \mathrm{mo}$, but the differences were not significant $(P \geq 0.15)$. Similar results were found for topsoil $\mathrm{NH}_{4}{ }^{+} \mathrm{N}$.

Effects of sampling date and stocking rate on topsoil C and $\mathrm{C} / \mathrm{N}$ were significant $(P \leq 0.05)$. Topsoil $\mathrm{C}$ varied $(P=0.02)$ with stocking rate in the order $2300 \mathrm{TPH}(1.57 \mathrm{~g}$ $\left.\mathrm{kg}^{-1}\right)>1200$ TPH $\left(1.47 \mathrm{~g} \mathrm{~kg}^{-1}\right)$, while $970 \mathrm{TPH}$ was intermediate $\left(1.54 \mathrm{~g} \mathrm{~kg}^{-1}\right)$. The $\mathrm{C} / \mathrm{N}$ ratio decreased $(P<0.01)$ between 0 mo (11.6) and 21 mo (10.9), while other dates were intermediate. The $1200 \mathrm{TPH}$ stocking rate (11.1) had lower $\mathrm{C} / \mathrm{N}(P=0.02)$ than the 970 or $2300 \mathrm{TPH}$ stocking rates (both 11.4).

Only the main effect of fertilizer was significant for topsoil $\mathrm{pH}(P=0.01)$. Means differed in the order PL ( $\mathrm{pH} 5.0)$ $>\mathrm{CF}(\mathrm{pH} 4.8$ ), with PPL intermediate at $\mathrm{pH} 4.9$ (data not shown). The PL and PPL have some liming capacity due to their Ca content (Table 1).

There were significant stocking rate $\mathrm{x}$ fertilizer interactions for extractable topsoil $\mathrm{Al}$ and available topsoil $\mathrm{P}$, which appeared to be caused by differences in soil nutrient trends and magnitudes with stocking rate (data not shown). Regression responses of the stocking rate $\mathrm{x}$ fertilizer interactions were non-significant $(P \geq 0.29)$ for either Al or $\mathrm{P}$. Extractable topsoil $\mathrm{Al}$ was greater $(P \leq 0.05)$ for $\mathrm{CF}$ than PL at 2300 and $1200 \mathrm{TPH}\left(61.6 \mu \mathrm{g} \mathrm{g}^{-1}\right.$ and $23.5 \mu \mathrm{g} \mathrm{g} \mathrm{g}^{-1}$, respectively), and intermediate for other fertilizer-stocking rate levels.

Fertilization caused a range of responses in available topsoil $\mathrm{P}$ that usually were poorly associated with stocking rate. At $2300 \mathrm{TPH}$, fertilizer treatments ranked $(P \leq 0.05)$ on the order $\mathrm{CF}>\mathrm{PL}>\mathrm{PPL}=$ control in available topsoil $\mathrm{P}$ 
(18.7, 12.4, 6.6, and $2.4 \mu \mathrm{g} \mathrm{g}^{-1}$, respectively). At $1200 \mathrm{TPH}$, fertilizer treatments ranked $(P \leq 0.05)$ on the order $\mathrm{CF}=\mathrm{PL}>$ PPL $>$ control in available topsoil $\mathrm{P}(17.5,14.8,9.2$, and 2.3 $\mu \mathrm{g} \mathrm{g}^{-1}$, respectively). At $970 \mathrm{TPH}$, fertilizer treatments ranked $(P \leq 0.05)$ on the order $\mathrm{PL}>\mathrm{CF}=\mathrm{PPL}=$ control in available topsoil $\mathrm{P}\left(13.5,6.0,5.3\right.$, and $1.8 \mu \mathrm{g} \mathrm{g}^{-1}$, respectively). Across stocking rates, $\mathrm{CF}$ (14.1 $\left.\mathrm{gg} \mathrm{g}^{-1}\right)$ and PL $\left(13.6 \mu \mathrm{g} \mathrm{g}^{-1}\right)$ did not differ significantly in available topsoil $\mathrm{P}$ and exceeded that of either PPL $\left(7.0 \mu \mathrm{g} \mathrm{g}^{-1}\right)$ and the control $\left(2.2 \mu \mathrm{g} \mathrm{g}^{-1}\right)$.
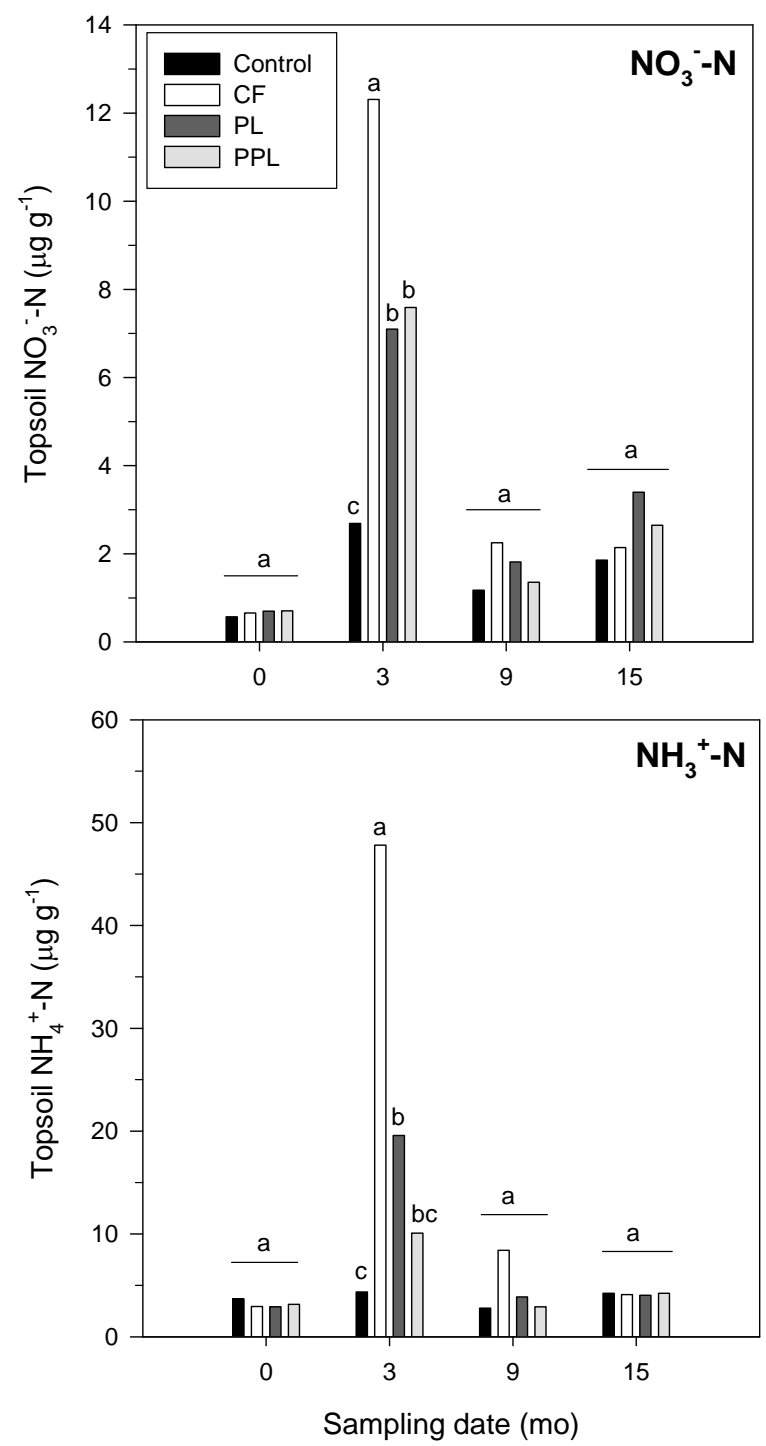

Fig. (5). Change in topsoil (0- to $10-\mathrm{cm}$ depth) $\mathrm{NO}_{3}{ }^{-}-\mathrm{N}$ and $\mathrm{NH}_{4}{ }^{+}-\mathrm{N}$ following fertilization (Control, $\mathrm{CF}=$ commercial fertilizer, $\mathrm{PL}=$ poultry litter, and PPL = pelletized poultry litter) for loblolly pine plantations near Booneville, AR. Fertilizer means within an evaluation date, or above a bar, followed by a common letter do not differ $(P>0.05)$.

\section{DISCUSSION}

\section{Tree Growth}

Pre-thinning fertilization of overstocked southern pines can cause a post-thinning yield response [10]. Further, fertilization with PL at 4.6 $\mathrm{Mg} \mathrm{ha}^{-1}$ increased BA of an 8- year-old, lightly stocked $\left(11 \mathrm{~m}^{2} \mathrm{ha}^{-1}\right)$ loblolly pine plantation in Mississippi [33]. We hypothesized that fertilization would also increase pre-thinning tree growth and pine straw yield. Basal area was high (32.6 to $42.8 \mathrm{~m}^{2} \mathrm{ha}^{-1}$ ) and did not respond to fertilization (Fig. 3 ).

Competition reduces growth of southern pines by affecting leaf area [34]. Competition-related mortality in intensively managed loblolly pine begins when BA reaches 30 to $35 \mathrm{~m}^{2} \mathrm{ha}^{-1}$ [35]. Similarly, annual stemwood biomass increment peaks as BA reaches 20 to $35 \mathrm{~m}^{2} \mathrm{ha}^{-1}$, and the maximum BA attained at canopy closure is 45 to $48 \mathrm{~m}^{2} \mathrm{ha}^{-1}$ [35]. Thus, the lack of a BA response to fertilization was attributed to overstocking.

\section{Foliar Responses}

The limitation in stand growth as planting density increases appears related to a site's capacity to support leaf area [34]. Thus, $\mathrm{N}$ fertilization should foster increased $\mathrm{N}$ assimilation and conversion leading to increased leaf area, leaf mass, pine straw yield, and increased stem diameter growth. We observed a transient foliar response to fertilization that diminished within 2 years after application regardless of stocking rate. Foliar $\mathrm{N}$ of loblolly and slash $(P$. elliottii Engelm.) pines decreases with increasing stocking rate, because the $\mathrm{N}$ sink of densely-stocked stands exceeds the soil $\mathrm{N}$ supply source [36].

Compared to the control, fertilization with PL caused only a transient increase in pine straw yield during 2006 and 2007 (Fig. 4). Pine straw yield at 2300 TPH was intermediate perhaps due to incipient competition-related mortality [D.M. Burner et al., 2009, unpublished data]. Mineral fertilizer and municipal sludge increased yield of pine straw from longleaf pine ( $P$. palustris Mill.) on a deep sand in South Carolina [9]. However, our findings generally support those of Haywood [37], who reported that fertilization of longleaf pine (P. palustris Mill.) in Louisiana over 15 years did not directly affect tree growth or pine straw yields at age 34 years, perhaps because of competition, repeated prescribed burning, and pine straw removal.

\section{Topsoil Nutrients}

Approximately two-thirds of total poultry litter $\mathrm{N}$ is in the organic fraction, and there is an initial rapid $\mathrm{N}$ release within $7 \mathrm{~d}$ of surface application, followed by a slower release during $90 \mathrm{~d}$ [38]. Two PL sources had 40 to $60 \%$ mineralization of initial organic- $\mathrm{N}$ within $120 \mathrm{~d}$ when incubated at $25^{\circ} \mathrm{C}$ under high humidity [39]. High topsoil $\mathrm{NO}_{3}{ }^{-} \mathrm{N}$ and $\mathrm{NH}_{4}{ }^{+}-\mathrm{N}$ at 3 mo was consistent with relatively low rainfall between 0 and 3 mo, and perhaps rapid $\mathrm{N}$ mineralization from PL $[37,39]$ and topsoil $\mathrm{NO}_{3}^{-}-\mathrm{N}$ from $\mathrm{CF}$ [40]. The temporal dynamic of topsoil $\mathrm{NO}_{3}{ }^{-} \mathrm{N}$ was very similar to that of a PL-fertilized loblolly pine plantation on a Paleudult topsoil in Mississippi [33], but differed somewhat from [39] who reported substantial soil $\mathrm{NO}_{3}{ }^{-} \mathrm{N}\left(\geq 125 \mathrm{mg} \mathrm{kg}^{-1}\right)$ $120 \mathrm{~d}$ after incorporation. Differences we detected among fertilizers in topsoil $\mathrm{NO}_{3}{ }^{-}-\mathrm{N}$ and $\mathrm{NH}_{4}{ }^{+}-\mathrm{N}$ responses might have been caused by differences in organic and mineral $\mathrm{N}$ fractions, while transient changes in topsoil $\mathrm{NO}_{3}{ }^{-} \mathrm{N}$ and $\mathrm{NH}_{4}{ }^{+}-\mathrm{N}$ concentrations might have been caused by mineralization of the organic fraction (Fig. 5). Persistence of relatively high topsoil $\mathrm{NH}_{4}^{+}-\mathrm{N}$ concentration at 3 mo was 
unexpected, because there was little available soil $\mathrm{NH}_{4}{ }^{+} \mathrm{N}$ $30 \mathrm{~d}$ after incorporating fresh PL in a controlled environment study [39].

Our results confirmed those for 4-year-old loblolly pine plantations [41] in which fertilization effected only a shortterm ( $\leq 2$ years) enhancement of soil available $\mathrm{N}$. While we failed to detect an effect of stocking rate on foliar $\mathrm{N}$, that of 4-year-old southern pines decreased from 12.2 to $10.1 \mathrm{~g} \mathrm{~kg}^{-1}$ of foliar $\mathrm{N}$ at 740 and 3,700 TPH, respectively [41]. Fertilization also had no effect on topsoil $\mathrm{C}$ concentrations or $\mathrm{C} / \mathrm{N}$ ratios for a loblolly pine plantation in Florida [42].

We confirmed an acidifying effect of $\mathrm{CF}$ on topsoil $\mathrm{pH}$ [43] relative to the Ca-induced liming effect of PL and PPL (Table 1). Increased $\mathrm{pH}$ resulting from application of PL and PPL fertilizers also could decrease exchangeable Al compared to CF and the unfertilized control [43], and some evidence of this response was observed for PL. Commercial fertilizer was expected to increase exchangeable Al because $\mathrm{NH}_{4} \mathrm{NO}_{3}$ decreases soil $\mathrm{pH}$ [43], but it was not clear why this response was confined to the $2300 \mathrm{TPH}$ stocking rate.

Available topsoil $\mathrm{P}$ in the control, 1.8 to $2.4 \mu \mathrm{g} \mathrm{g}^{-1}$, was below the reported critical range of 3 to $5 \mu \mathrm{g} \mathrm{g}^{-1}$ [44]. All fertilization treatments except PPL generally increased available topsoil $\mathrm{P}$ compared to the control, but fertilization generally failed to boost tree growth probably due to high stocking rate. Concentrations of topsoil $\mathrm{P}$ were similar to those of this study, and also differed little from the control, for a loblolly pine plantation fertilized with $4.6 \mathrm{Mg} \mathrm{PL} \mathrm{ha}^{-1}$ in Mississippi [33]. The topsoil P concentration of a loblolly plantation in Florida also was not affected by fertilization, although fertilization increased $P$ mineralization [42]. Since total litter P includes about $54 \%$ organic and $41 \%$ inorganic fractions [45], it seemed likely that P mineralization differed among fertilizers [38, 46]. Competition also might have altered the understory microenvironment, such as soil water potential [47], affecting P mineralization and P utilization.

A constraint to this study was that fertilizers were broadcast applied to a ground surface which was covered with pine straw, the usual method for fertilizing pine stands $[9,12,33]$. Since the fertilizer granules have poor soil contact there is risk of $\mathrm{N}$ loss through $\mathrm{NH}_{4}{ }^{+} \mathrm{N}$ nitrification [48]. Further, above normal rainfall after 3 mo (Fig. 1) might have caused the system to lose $\mathrm{N}$ through surface runoff. Thus, surface application might have reduced $\mathrm{N}$ available for tree use. While alley tillage is generally impractical and unadvised in pine stands [20], mechanized subsurface banding technology is being developed for perennial grasslands which reduces N and P loss in runoff [49]. Such technology might eventually be adapted to pine plantations.

Contrary to our hypothesis, the response to fertilization was mitigated by stocking rate. Stocking rate had a greater effect than fertilization on BA. While fertilization per se rarely increased pine straw yield compared to the control, it increased $\mathrm{N}$ concentration in pine straw and foliage suggesting that slow $\mathrm{N}$ release from litter might benefit tree growth and pine straw yield at lower stocking rate. While the plantations were able to acquire $\mathrm{N}$, overstocking seemed to constrain $\mathrm{N}$ utilization for increased $\mathrm{BA}$ or foliage production. Future research should include an evaluation of post-thinning growth and yield responses as influenced by pre-thinning fertilization.

\section{ACKNOWLEDGEMENTS}

The authors appreciate the foresight of Dr. Henry Pearson (USDA-ARS, retired) who designed and planted this experiment. Perdue AgriRecycle LLC, Seaford, DE, USA donated the Microstart $60^{\mathrm{TM}}$ pelletized poultry litter. Steve Haller (USDA ARS, Booneville, AR, USA) assisted with litter applications, and Karen Chapman and Jim Whiley (USDA ARS, Booneville, AR, USA) assisted with tree measurements and sample analyses. Mention of trade names or commercial products in this article is solely for the purpose of providing specific information and does not imply recommendation or endorsement by the USDA.

\section{ABBREVIATIONS}

$\mathrm{BA}=$ Basal area
$\mathrm{CF}=$ Commercial fertilizer
$\mathrm{PL}=$ Poultry litter
$\mathrm{PPL}=$ Pelletized poultry litter $^{-1}$
$\mathrm{TPH}$

\section{REFERENCES}

[1] Beckwith JR III, Dangerfield CW Jr, Moorhead DJ. Quality wood products from Georgia forestry, FOR 97-009. (updated 1997 Aug, cited 2010 Feb 11). Warnell School of Forestry and Natural Resources, Univ Georgia, Athens. Available from: http://warnell.forestry.uga.edu/serv ice/library/index.php3?docID=135\&docHistory []$=14$

[2] Haynes RW. An analysis of the timber situation in the United States: 1989-2040 - A Technical document supporting the 1989 USDA Forest Service RPA assessment. GTR-RM-199. US For Serv, Rocky Mountain Forest and Range Exp Stn, Fort Collins, CO; 1990. Available from: http://www.fs.fed.us/rm/pubs_rm/rm_gtr199.html

[3] Schultz RP. Loblolly pine. US For Serv, Agric Handb 713. US Gov Print Off, Washington, DC 1997.

[4] Rosson JR Jr, London JD. Forest statistics for Arkansas' Ouachita counties - 1995. RB-SRS-010. US For Serv, South Res Stn, Asheville, NC; 1997. Available from: http://www.srs.fs.usda.gov/pubs/1632

[5] Carson JB. Pine straw mulch in the landscape. FSA6044. Univ Arkansas, Coop Ext Serv, Little Rock, AR 1994.

[6] Casanova V, Malki M. Raking it in: the political economy of pine straw. Annual meeting of the Rural Sociological Society, Seelbach Hilton Hotel, Louisville, Kentucky, 2006 (updated 2009 May 25, cited 2010 Feb 11). Available from: http://www.allacademic.com/meta/p1 24988_index.html

[7] Dickens ED, Dangerfield CW Jr, Moorhead DJ. An economic comparison of slash and loblolly pine under various levels of management in the lower Atlantic and Gulf Coastal Plain. In: Connor $\mathrm{KF}$, Ed. Proceedings of the $13^{\text {th }}$ biennial southern silvicultural research conference. GTR-SRS-92. US For Serv, South Res Stn, Asheville, NC 2006; pp. 351-6. Available from: http://www.srs.fs.usda.gov/pubs/ 23305

[8] Moore BJ, Roth FA II, Pearson HA, Haywood JD. Pine straw harvesting: a new Arkansas agricultural enterprise. MP382-2M-9-96. Univ Arkansas, Coop Ext Serv, Little Rock, AR 1996.

[9] Dickens ED. Effect of inorganic and organic fertilization on longleaf pine tree growth and pine straw production. In: Haywood JD, Ed. Proceedings of the $10^{\text {th }}$ biennial southern silvicultural research conference. GTR-SRS-30. US For Serv, South Res Stn, Asheville, NC; 1999; pp. 464-8. Available from: http://www.srs.fs.usda.gov/pubs/1171

[10] Dickens ED, Moorhead DJ, Morris LA, McElvany BC. Straw raking in southern pine stands and fertilization recommendations. 2004 (cited 2010 Feb 11). Univ. Georgia, Warnell School Forestry and Natural Resources, Univ Georgia, Athens. Available from: http://www.forest productivity.net/pdfs/Pine\%20straw\%20ext\%20pub\%2003-04.pdf

[11] Boatright SR, McKissick JC. 2006 Georgia farm gate value report. AR07-01. 2007 (cited 2010 Feb 11). Univ. Georgia, Center for 
Agribusiness and Economic Development, Athens. Available from: http://www.caed.uga.edu/publications/2007/pdf/AR-07-01.pdf

[12] Jokela EJ. Nutrient management of southern pines. In: Dickens ED, Barnett JP, Hubbard WG, Jokela EJ, Eds. Slash pine: still growing and growing! Proceedings of the slash pine symposium. GTR-SRS-76. US For Serv, South Res Stn, Asheville, NC; 2004; pp. 27-35. Available from: http://www.srs.fs.usda.gov/pubs/8435

[13] Blazier MA. Fertilizing southern pine plantations to improve growth and financial performance. Publ. 3058. 2008 (cited 2010 Feb 11). LSU AgCenter Res Ext, Baton Rouge, LA. Available from: http://www. lsuagcenter.com/NR/rdonlyres/C8B9CA8A-3F5C-4703-A883-FEAAB 6675871/49203/pub3058FertilizingsouthernpinesLOWRES.pdf

[14] Lichtenberg E, Parker D, Lynch L. Economic value of poultry litter supplies in alternative uses. Policy analysis Rep No 02-02. c2002 (cited 2010 Feb 11). Center for Agricultural and Natural Resource Policy, Univ Maryland, College Park. Available from: http://www.arec.umd. edu/Extension/WaterQuality/02-02.pdf

[15] Lynch L, Tjaden R. Would forest landowners use poultry litter as fertilizer? J For 2004; 102: 40-5.

[16] Dickens ED, Richardson BW, McElvany BC. Old-field thinned loblolly pine plantation fertilization with diammonium phosphate plus urea and poultry litter -4 year growth and product class distribution results. In: Connor KF, Ed. Proceedings of the $12^{\text {th }}$ Bien South Silvicult Res Conf, GTR-SRS-71. US For Serv, South Res Stn, Asheville, NC 2004; pp. 395-7. Available from: http://www.srs.fs.usda.gov/pubs/6304

[17] Burner DM, MacKown CT. Herbage nitrogen recovery in a meadow and loblolly pine alley. Crop Sci 2005; 45: 1817-25.

[18] Pote DH, Grigg BC, Blanche CA, Daniel TC. Effects of pine straw harvesting on quantity and quality of surface runoff. J Soil Water Conserv 2004; 59: 197-203.

[19] Walkingstick T, Voth DE, Williams RA, Earl J, Hill CP. A characterization of the nonindustrial private forest landowners of Arkansas. In: Guldin JM, Ed. Proceedings of the Symposium on Arkansas forests: A conference on the results of the recent forest survey of Arkansas; 1997 May 30-31, North Little Rock, AR. GTR-SRS-41. US For Serv, South Res Stn, Asheville, NC 2001. Available from: http://www.srs.fs.usda.gov/pubs/2793

[20] Burner DM, Pote DH, Belesky DP. Effect of loblolly pine (Pinus taeda L.) root pruning on alley cropped herbage production and tree growth. Agron J 2009; 101: 184-92.

[21] Carmean WH, Hahn JT, Jacobs RD. Site index curves for forest tree species in the eastern United States. US For Serv, North Central Forest Exp. Stn. GTR-NC-128, St. Paul, MN; 1989; Fig. 115, p. 130. Available from: http://nrs.fs.fed.us/pubs/192

[22] Arkansas Forestry Commission [seedling sales homepage on the internet] Little Rock, AR. c2005 (cited 2010 Feb 11). Available from http://www.arkansasforestry.org/seedlingsales_new.htm

[23] Burner DM, Brauer DK. Herbage response to spacing of loblolly pine trees in a minimal management silvopasture in southeastern USA. Agrofor Syst 2003; 57: 69-77.

[24] Perdue AgriRecycle [homepage on the internet] Seaford, DE: Perdue AgriRecycle, LLC. c2006 (cited 2010 Feb 11). Available from http://www.perdueagrirecycle.com/

[25] Wells C, Allen L. A loblolly pine management guide: when and where to apply fertilizer. GTR-SE-36. US For Serv, South Res Stn, Asheville, NC; 1985. Available from: http://www.srs.fs.usda.gov/pubs/ 921

[26] Zhang S, Allen HL. Foliar nutrient dynamics of 11-year-old loblolly pine (Pinus taeda) following nitrogen fertilization. Can J For Res 1996; 26: 1426-39.

[27] Avery TE, Burkhart HE. Forest measurements. $4^{\text {th }}$ ed. Boston: McGraw-Hill 1994.

[28] Dougan WK, Wilson AL. The absorptiometric determination of aluminium in water. A comparison of some chromogenic reagents and the development of an improved method. Analyst 1974; 99: 413-30.

[29] Mehlich A. Mehlich 3 soil test extractant: A modification of the Mehlich 2 extractant. Commun Soil Sci Plant Anal 1984; 15: 1409-16.

[30] National Oceanic and Atmospheric Administration (NOAA). Climatography of the United States No 81, Arkansas. National Climatic
Data Center, Asheville, NC; 2002. Available from: http://wf.ncdc.n oaa.gov/oa/climate/normals/usnormalsprods.html\#CLIM81

[31] SAS Institute. SAS/STAT user's guide. Release 9.1. Windows version 5.1.2600. SAS Institute, Cary, NC; 2002.

[32] Littell RC, Milliken GA, Stroup WW, Wolfinger RD. SAS System for Mixed Models. SAS Institute Inc., Cary, NC 1996.

[33] Friend AL, Robert SD, Schoenholtz SH, Mobley JA, Gerard PD. Poultry litter application to loblolly pine forests: growth and nutrient containment. J Environ Qual 2006; 35: 837-48.

[34] Dickens ED, Wills RE. Planting density impacts on slash pine stand growth, yield, product class distribution, and economics. In: Dickens ED, Barnett JP, Hubbard WG, Jokela EJ, Eds. Slash pine: still growing and growing! Proceedings of the slash pine symposium, GTR-SRS-76. US For Serv, South Res Stn. Asheville, NC; 2004; pp. 36-44. Available from: http://www.srs.fs.usda.gov/pubs/8435

[35] Jokela EJ, Dougherty PM, Martin TA. Production dynamics of intensively managed loblolly pine stands in the southern United States: a synthesis of seven long-term experiments. For Ecol Manage 2004; 192: 117-30.

[36] Will RE, Barron-Gafford G, Teskey RO, Shiver BD. Within and between canopy variability of foliar nitrogen concentration for loblolly and slash pine stands planted at different densities. In: Connor KF, Ed. Proceedings of the 12th biennial southern silvicultural research conference. GTR-SRS-71. US For Serv, South Res Stn. Asheville, NC; 2004; pp. 407-10. Available from: http://www.srs.fs.usda.gov/ pubs/6304

[37] Haywood JD. Influence of pine straw harvesting, prescribed fire, and fertilization on a Louisiana longleaf pine site. South J Appl For 2009; 33: $115-20$.

[38] Hadas A, Bar-Yosef B, Davidov S, Sofer M. Effect of pelleting, temperature, and soil type on mineral nitrogen release from poultry and dairy manures. Soil Sci Am J 1983; 47: 1129-33.

[39] Preusch PL, Adler PR, Sikora LJ, Tworkoski TJ. Nitrogen and phosphorus availability in composted and uncomposted poultry litter. J Environ Qual 2002; 31: 2051-7.

[40] Bambo SK, Nowak J, Blount AR, Long AJ, Osiecka A. Soil nitrate leaching in silvopastures compared with open pasture and pine plantation. J Environ Qual 2009; 38: 1870-7.

[41] Johnson DW, Todd DE. Nitrogen fertilization of young yellow poplar and loblolly pine plantations at differing frequencies. Soil Sci Soc Am J 1988; 52: 1468-77.

[42] Polglase PJ, Comerford NB, Jokela EJ. Mineralization of nitrogen and phosphorus from soil organic matter in southern pine plantations. Soil Sci Soc Am J 1992; 56: 921-7.

[43] Moore PA Jr, Edwards DR. Long-term effects of poultry litter, alumtreated litter, and ammonium nitrate on aluminum availability in soils. J Environ Qual 2005; 34: 2104-11.

[44] Dickens ED, Moorhead DJ, McElvany B. Georgia pine plantation fertilization. Better Crops 2003; 8: 12-5. Available from: http://www. forestproductivity.net/fertilization/Better $\% 20 \mathrm{Crops} \% 20 \mathrm{Fert} \% 20$ article \%2003-1p12.pdf

[45] Dao TH, Hoang KQ. Dephosphorylation and quantification of organic phosphorus in poultry litter by purified phytic-acid high affinity Aspergillus phosphohydrolases. Chemosphere 2008; 72: 1782-7.

[46] Griffin TS, Honeycutt CW, He Z. Changes in soil phosphorus from manure application. Soil Sci Soc Am J 2003; 67: 645-53.

[47] Grierson PF, Comerford NB, Jokela EJ. Phosphorus mineralization and microbial biomass in a Florida Spodosol: effects of water potential, temperature and fertilizer application. Biol Fertil Soils 1999; 28: 24452.

[48] Kissel DE, Cabrera ML, Vaio N, Craig JR, Rema JA, Morris LA. Rainfall timing and ammonia loss from urea in a loblolly pine plantation. Soil Sci Soc Am J 2004; 68: 1744-50.

[49] Pote DH, Way TR, Sistani KR, Moore PA Jr. Water-quality effects of a mechanized subsurface-banding technique for applying poultry litter to perennial grassland. J Environ Manage 2009; 90: 3534-9.

This is an open access article licensed under the terms of the Creative Commons Attribution Non-Commercial License (http://creativecommons.org/licenses/bync/3.0/) which permits unrestricted, non-commercial use, distribution and reproduction in any medium, provided the work is properly cited. 